Yugoslavia in Slovenia, and became a cult book. The author refers to the same characters and their evolution over the past ten years, a special place in the text is given to Bosnia and the life of the main protagonist there. The clash and overlap of different cultural spaces leads to complex forms of transculturalism, which are reflected in the work in the form of various forms of linguistic hybridity, bifurcated, nomadic identity of characters, actualization of the problem of migration as such.

М. М. Гролова (Москва, Россия)

\title{
Словенские народные сказки и легенды в переводах на русский язык (с 1991 г. по настоящее время)
}

Словенские народные сказки, активно собираемые и изучаемые на родине, русскоязычным читателям известны сравнительно мало. Их первые публикации на русском языке появляются во второй половине XIX в. в качестве иллюстративного материала в исследованиях видных ученыхславистов Ф.И. Буслаева и И.А. Бодуэна де Куртенэ, а затем и в популярных сборниках славянских сказок. После революции словенские сказки появляются в советских изданиях лишь по окончании советско-югославского конфликта 1948-1953 гг., причем дореволюционные переводы не перепечатываются.

В первые годы после распада СССР многочисленные новообразованные издательства охотно печатают сборники сказок - как правило, копии советских изданий или компиляции. Новые переводы сказок в это время редки: издательства в целях экономии обращаются к уже имеющимся. Переводы словенских сказок, выполненные в советский период, печатают до сих пор. Зачастую фрамилию переводчика 
в таких изданиях не указывают, вероятно, пытаясь избежать проблем с авторскими правами. Публикации словенских сказок без сведений о переводчике, многочисленные в первые десятилетия после распада СССР, постепенно сходят на нет и после 2009 г. встречаются только в сборниках харьковского издательства «Клуб семейного досуга».

Ввиду небрежности издателей сборников сказок и «самых полных» хрестоматий последнего десятилетия зачастую возникает путаница. Так, регулярно «становится» словенской словацкая сказка «У солнышка в гостях». То словенской, то словацкой именуется докучная сказка неизвестного происхождения «Шла мышка через мостик» в переводе Л. Яхнина. В «Большую книгу рождественских сказок» («Лениздат», 2007) вошла под видом словенской норвежская сказка «Белый медведь - король Валемон».

Появляются публикации словенских сказок в новых фрорматах. Так, в 1999 г. в детском журнале «Костер» (№ 8) публикуется сказка «Водяной» в виде комикса.

Часто переиздаются дореволюционные переводы, перешедшие за давностью лет в общественное достояние (также без указания фрамилии переводчика, т. е. с нарушением неимущественных авторских прав). Не избежали подобной участи и «словинские» сказки, опубликованные в популярном сборнике «Сказки славянских народов» (1899): они были переизданы как минимум дважды — в 1991 и 2020 г.

В 2012 и 2020 гг. выходит репринтное переиздание второго тома «Материалов для южнославянской диалектологии и этнографии» (1904) И. А. Бодуэна де Куртенэ, в котором содержится значительное количество записей сказок и рассказов-анекдотов, переведенных исследователем с терского диалекта словенского языка.

Новые переводы словенских народных сказок начинают появляться только с 2001 г. в нишевых или маргинальных изданиях. Так, народный сказ «Курент» в переводе Г. Замятиной включен в монографию «Словенская литература 
(от истоков до рубежа XIX-XX вв.)» (Словенская литература 2010: 74-79), а в 2020 г. в журнале «Живая старина» опубликована «сказка для взрослых», записанная в 1872 г. в с. Чигинь, в переводе М.Ясинской (Иванчич Кутин, Кенда-Еж 2020: 16-19).

В 2001 г. шесть словенских сказок в переводах словенцев Ирены, Сони-Марии и Бориса Ругелов (Ругел 2001: 240-246) опубликованы в сборнике «Словенско-русский альманах» (тираж 3000 экз.), который наряду с художественными произведениями известных словенских поэтов и статьями современных российских филологов включает псевдонаучные статьи словенских и российских представителей фолк-хистори.

В последние годы официально переиздаются детские книги 1970-1980-х гг., в том числе включающие словенские народные сказки. Так, в 2016 г. тиражом 5000 экз. переиздан сборник славянских сказок «Ни далеко, ни близко, ни высоко, ни низко», выходивший в 1976 г., а в 2018 г. тиражом 4000 экз. переиздан сборник «Сказки гор» (1987).

С 2012 г. публикации словенских сказок и легенд появляются в сети Интернет: энтузиасты переводят их «для души» и выкладывают в свободный доступ на собственных сайтах и в соцсетях. Так, выпускница МГУ им. М. В. Ломоносова, доцент Вильнюсского университета, кавалер Ордена Республики Словения за заслуги Елена Коницкая (р. 1958) перевела и опубликовала на своем сайте 13 сказок из Венецианской Словении (Коницкая 2012). Волшебную сказку «Янчек-ежик», несколько словенских преданий и шуточных историй перевела и опубликовала в социальной сети «ВКонтакте» автор данной работы (Громова 2019).

Резьянские сказки о животных (zverinice iz Rezije), записанные словенским фольклористом академиком Милко Матичетовым, давно стали «визитной карточкой» Резии и весьма популярны в Словении (в том числе в виде кукольных спектаклей и мультфильмов). Однако до сих пор русскоязычные читатели могут ознакомиться с фольклором 
долины Резия только в интернет-публикациях. В 2019 г. в социальной сети «ВКонтакте» автор данной работы опубликовала семь резьянских сказок о животных из собрания Милко Матичетова в собственном переводе со словенского (Громова 2019). В 2015 г. в той же соцсети были опубликованы резьянские легенды «Дуяцесса» и «Дыра в горе Канин» в переводе С. Реутта (Реутт 2015a; 2015b), в 2017 г. — резьянская сказка «На Рождество» в переводе с итальянского А. Гладкого под ред. С. Реутта (Гладкий 2017).

С самого начала публикаций в популярных изданиях словенские народные сказки выходили на русском языке исключительно в составе сборников («Славянские сказки», «Югославские сказки» и т. п.), антологий и хрестоматий. Только в 2013 г. вышло первое отдельное издание словенских народных сказок на русском языке - сборник-билингва «Лучшие сказки Словении / Najlepše slovenske pravljice» (Кунавер 2013). В книгу вошли пять сказок в переводе Марины Билаш, записанных собирательницей словенского фольклорного и этнографического материала Душицей Кунавер (р. 1937) и ранее не издававшихся на русском языке. Сборник адресован русскоязычным читателям, интересующимся словенским культурным наследием, и словенцам, изучающим русский язык.

В 2022 г. в издательстве «Стрекоза» впервые готовится к выходу на русском языке сборник, содержащий исключительно словенские (в том числе резьянские) народные сказки и рассчитанный на самую широкую аудиторию. Это объемный сборник «Триста зайцев», составленный словенской фольклористкой, поэтессой и профессиональной сказительницей Аней Штефан (р. 1969) по материалам Милко Матичетова и вышедший на словенском языке к столетию со дня его рождения. Перевод на русский язык подготовлен автором настоящей статьи. В сборник вошли как резьянские сказки о животных, хорошо известные словенским читателям, так и ранее не издававшиеся сказки, расшифрованные 
составительницей по рукописям и магнитофонным пленкам из личного архива Милко Матичетова и архива Словенского этнографического института Научно-исследовательского центра Словенской академии наук и искусств. 39 сказок, вошедших в сборник, Милко Матичетов записал с 1940 по 1973 г. от сказителей разного возраста и из различных словенскоговорящих регионов (преимущественно из долины Резия в Италии и Нижней Крайны в Словении). Сборник оформлен наиболее известными словенскими иллюстраторами детских книг.

\section{Литература}

Гладкий 2017 - На Рождество / пер. с ит. А. Гладкого; под ред. С. Реутта // На Рождество (Vinahte). 06.01.2017. URL: https://vk.com/wall57515704_9337 (дата обращения: 21.01.2021).

Громова 2019 - Проникнуться Словенией / [пер. со словен. М. Громовой]. 2019-2020. URL: https://vk.com/wall-168887269?q=\%23\%D0\%B F\%D0\%B5\%D1\%80\%D0\%B5\%D0\%B2\%D0\%BE\%D0\%B4 (дата обращения: 31.08.2021).

Иванчич Кутин, Кенда-Еж 2020 - Иванчич Кутин Б., Кенда-Еж К. "Сказка для взрослых", записанная в 1872 г. в с. Чигинь в Словении / пер. со словен. М.В.Ясинской // Живая старина. 2020. № 3 (107). C. 16-19.

Коницкая 2012 - Словенские сказки. 21.08.2012. URL: https://jelkon. jimdofree.com/словенские-сказки/ (дата обращения: 21.01.2021).

Кунавер 2013 - Лучшие сказки Словении = Najlepše slovenske pravljice / пер. Марины Билаш; сост. Душица Кунавер. М.: Билингва, 2013. [+ CD]

Реутт 2015b - Дыра в горе Канин (резьянская легенда) / пер. С. Реутта // Ta göra śis jamo tana Ćjaninu (Дыра в горе Канин). 04.03.2015. URL: https://vk.com/wall-57515704_5429 (дата обращения: 21.01.2021).

Реутт 2015a - Дуяцесса (резьянская легенда) / пер. С. Реутта // Duiacessa (Дуяцесса). 18.03.2015. URL: https://vk.com/wall-57515704_5658 (дата обращения: 21.01.2021).

Ругел 2001 - Словенско-русский альманах. История, языкознание, публицистика, художественная литература Словении, справочные материалы по Словении, карты / автор замысла, сост. и отв. ред. Юст Ругел; ред. и консультант О. Плотникова. М.; Зеленоград: Д-р Франце Прешерн: ЖАГ-ВМ, 2001. 
Словенская литература 2010 - Словенская литература (от истоков до рубежа XIX-XX вв.) / Ин-т славяноведения РАН; Науч-исслед. центр Словен. акад. наук и искусств; [отв. ред. Н. Н. Старикова]. М.: Индрик, 2010.

\section{Translations of Slovenian Folk Tales into Russian (from 1991 to the present)}

The work examines Russian-language publications of Slovenian folk tales, traditions and legends in the period from 1991 to the present, including on the Internet.

DOI:10.31168/0459-6.45

E. В. Байдалова (Москва, Россия)

Литературное творчество В. К. Винниченко как объект изучения

В. К. Винниченко (1880-1951) - один из наиболее выдающихся украинских писателей первой трети XX в., однако его художественные эксперименты неоднозначно оценивались современниками. При этом интерес к его творчеству был огромен: о нем писали такие разные авторы, как И. Франко, И. Нечуй-Левицкий, Л. Украинка и практически все видные украинские литературоведы и критики, среди которых С. Ефремов, А. Никовский, М. Евшан, М. Зеров и др. Даже В. И. Ленин, пусть негативно («ахинея и глупость», «архискверное подражание архискверному Достоевскому», «муть, ерунда»), но высказался об одном из романов украинского писателя в письме к И.Арманд (Ленин 1964: 294-295). Следует отметить, что в большинстве работ основное внимание уделялось содержанию произведений, неординарным идеям автора.

В 1920-х гг. появились первые сборники статей и монографии о творчестве Винниченко, написанные в русле социо- 